Article

\title{
Identity and Seasonal Abundance of Beneficial Arthropods Associated with Big Sagebrush (Artemisia tridentata) in Central Washington State, USA
}

\author{
David G. James *, Lorraine Seymour, Gerry Lauby and Katie Buckley \\ Department of Entomology, Washington State University, Irrigated Agriculture Research and Extension Center, \\ 24106 North Bunn Road, Prosser, WA 99350, USA; lorraine.seymour@pnnl.gov (L.S.); glauby@wsu.edu (G.L.); \\ katie.buckley@wsu.edu (K.B.) \\ * Correspondence: david_james@wsu.edu, Tel.: +1-509-786-9280
}

Received: 13 March 2018; Accepted: 21 June 2018; Published: 28 June 2018

check for updates

\begin{abstract}
Big sagebrush (Artemisia tridentata) characterizes and dominates the sagebrush steppe, the largest temperate semi-desert ecosystem in North America. The beneficial arthropod fauna hosted by $A$. tridentata is poorly known but could be of importance to nearby agriculture seeking to exploit biologically-based pest management. Over four years, we identified and assessed the seasonal abundance of beneficial arthropods (predators, parasitoids, pollinators) associated with A. tridentata during spring to autumn in the Yakima Valley of central Washington using sticky traps. During 2011-2014, 207 sticky traps were placed on non-blooming and blooming A. tridentata plants for a total of 966 trapping days. Overall, across all seasons, we trapped 259.7 beneficial arthropods per trap and $92 \%$ of these were parasitoid wasps. Significantly greater numbers of beneficial arthropods were associated with blooming $A$. tridentata during autumn (410/trap) than non-blooming plants in the spring (181.3/trap) or summer (85.1/trap). Parasitoid wasps and predatory true bugs were most abundant during the autumn, but ladybeetles, lacewings, spiders, bees, and predatory thrips were most common during spring. The association of high numbers of predators, parasitoids, and pollinators with $A$. tridentata during blooming and non-blooming periods indicates that this plant is an important reservoir of beneficial arthropods in the sagebrush steppe of central Washington. Consequently, biologically-based pest management programs in central Washington may benefit from careful management and retention of $A$. tridentata plants on crop borders.
\end{abstract}

Keywords: predators; parasitoids; pollinators; crop pest management; sagebrush steppe; blooming; non-blooming

\section{Introduction}

Big sagebrush (Artemisia tridentata Nuttall) is a long-lived, widespread shrub that characterizes and dominates the shrub or sagebrush steppe, the largest temperate semi-desert ecosystem in North America [1,2]. It occurs from southern British Columbia to northern Baja Mexico and from the Dakotas and Nebraska to Washington, Oregon, and California, although its range has been greatly reduced and fragmented in recent decades [3]. Before agricultural development, the sagebrush steppe covered an estimated 38.6 million square kilometers, but today it occupies about half (56\%) of its historic range [3]. The arthropod fauna of $A$. tridentata has been little studied, although recent research in Idaho indicates that the assemblage is large and diverse [4-6]. Specific arthropod species or communities and dynamics on A. tridentata have also been studied in Wyoming [7], California [8], Oregon [9], Utah [10,11], and Washington [12]. Numbers of arthropod species recorded on A. tridentata range from 106 to 232 in Idaho [4,6] and 168 in central Oregon [9]. A diverse and relatively large fauna (65 taxa) of beneficial insects and spiders was recorded on A. tridentata during spring to autumn in central Washington [12]. 
Agricultural development has occurred in many areas of the sagebrush steppe in the Pacific Northwest and is a significant driver in the decline of this ecosystem [3]. For example, large areas of sagebrush have been cleared in central Washington over the past 70 years to make way for extensive agricultural production based on wheat, potatoes, pome fruit, grapes, hops, and other horticultural and broadacre crops [13]. As crop pest management moves away from intensive chemical control to more biologically-based systems [14], increased attention is being given to the role and importance of natural plant communities in providing resources for beneficial arthropods [15]. Restoration of native plants and native plant communities can enhance populations of natural enemies of pest species, improving conservation biological control and reducing chemical inputs and costs in crop production [16]. Habitat restoration in and around croplands has also shown value for conserving wildlife including reptiles and mammals [17], birds [18], and butterflies [19].

Habitat restoration on cultivated land in central Washington agriculture occupying former sagebrush-steppe landscapes must consider the importance of $A$. tridentata as a host for beneficial arthropods, given its dominance in the sagebrush-steppe landscape. Previous studies have shown the importance of other sagebrush-steppe and riparian native plants like desert buckwheats (Eriogonum spp.), nettles (Urtica spp.), and milkweeds (Asclepias spp.) in attracting and retaining a range of beneficial arthropods [20-22]. While buckwheats occupy a similar area to A. tridentata (although plant densities are much smaller), nettles and milkweeds are generally confined to riparian zones within the sagebrush steppe. Seven native plants (including A. tridentata) surveyed in eastern Washington hosted varying numbers of predatory and parasitic arthropods [12].

This study identifies the major groups of beneficial arthropods (predators, parasitoids, pollinators) in the Yakima Valley of central Washington that are associated with A. tridentata and provides data on their seasonal abundance.

\section{Materials and Methods}

\subsection{Sites}

This study was conducted over four seasons (2011-2014) in central Washington by counting and identifying beneficial arthropods associated with big sagebrush (Artemisia tridentata Nutt.) using transparent sticky traps. Artemisia tridentata plants were located in natural areas at five locations in the Yakima Valley (Red Mountain $\left(46.17^{\circ} \mathrm{N}, 119.26^{\circ} \mathrm{W}\right)$, Cowiche Mountain $\left(46.39^{\circ} \mathrm{N}, 120.46^{\circ} \mathrm{W}\right)$, Prosser $\left(46.14^{\circ} \mathrm{N}, 119.42^{\circ} \mathrm{W}\right)$, North Prosser $\left(46.18^{\circ} \mathrm{N}, 119.45^{\circ} \mathrm{W}\right)$, Horn Rapids $\left(46.22^{\circ} \mathrm{N}, 119.26^{\circ} \mathrm{W}\right)$ ) (Figure 1).

\subsection{Traps and Trapping}

Transparent sticky traps (WindowBugCatcher, $40.6 \times 12.1 \mathrm{~cm}^{2}$, Alpha Scents Inc., Portland, OR, USA) were used, so that trap color did not influence insect attraction. At each site and on each occasion, a single trap was placed on each of three plants. Plants with traps were at least $5 \mathrm{~m}$ from other plants/traps and traps were attached to plants 1-2 $\mathrm{m}$ above ground level using flexible wires. Traps were left in place for 12-14 days before being removed and replaced. In less than 20 instances follow-up trapping occurred on the same plants (when plant numbers were limited) but usually different plants were chosen. Trapping was conducted during spring (April-May 2012, 2014: 224 total trapping days, non-blooming), summer (June-August 2012, 2014: 196 total trapping days non-blooming), and autumn (late September-October 2011, 2012, 2013: 546 total trapping days, blooming) using a total of 207 sticky traps. Availability of resources and funding dictated trapping regimes within and across years. During blooming, traps were placed over flowers. Traps collected from the field were transported to the laboratory and stored at $-30{ }^{\circ} \mathrm{C}$ until examined under a stereomicroscope. 


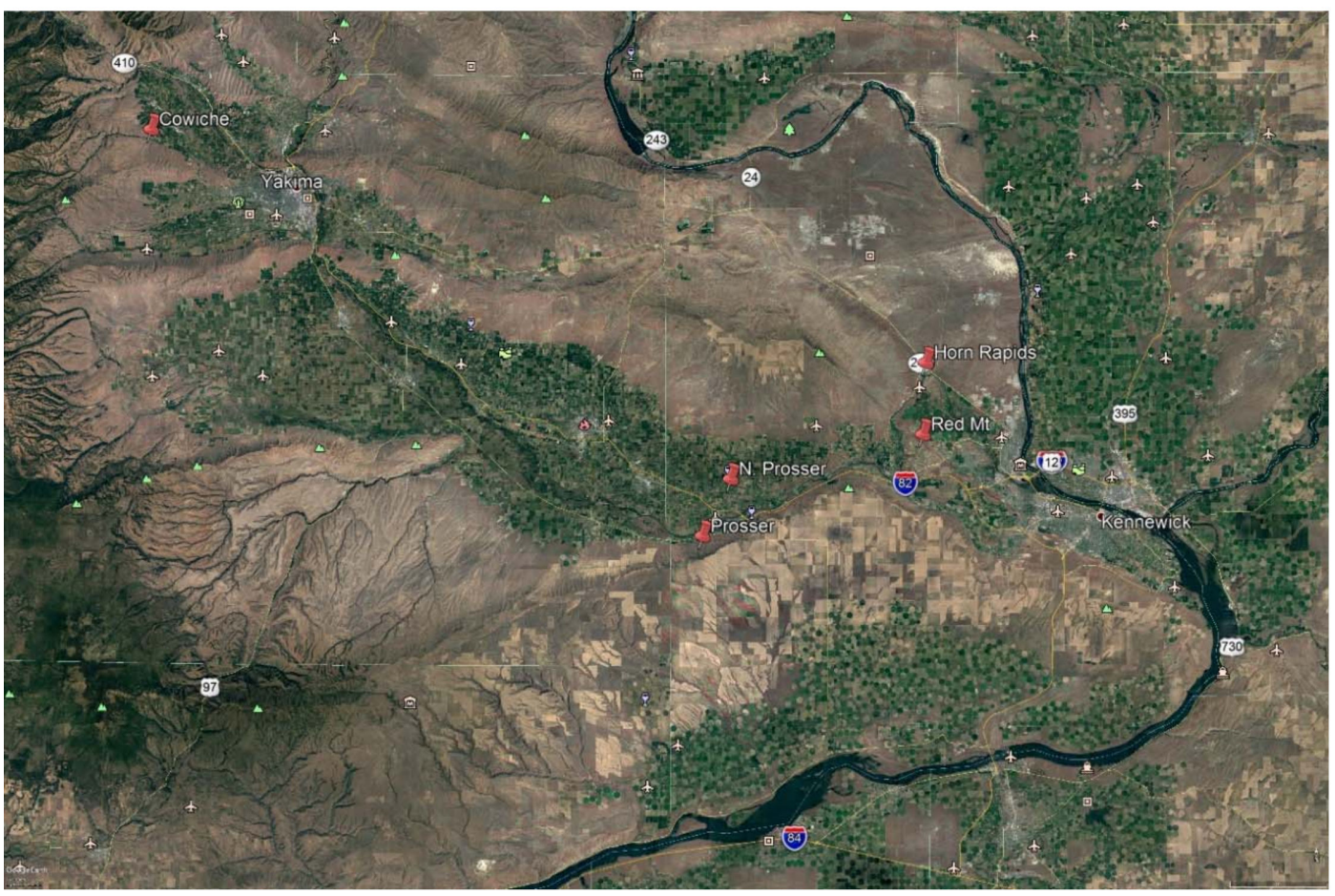

Figure 1. Eastern Washington State, USA, showing locations (red pins) of Artemisia tridentata sampled for beneficial arthropods.

\subsection{Arthropod Identification}

All arthropods were identified to family or species and counted. The incidence and abundance of 34 species, genera, or groups of beneficial insects and spiders were recorded (Table 1). Numbers of leafhoppers (Erythroneura spp.) were also recorded.

Beneficial arthropods were condensed into 10 categories for analysis: lacewings (Chrysopidae), ladybeetles (Coccinellidae), predatory true bugs (Miridae, Anthocoridae), predatory thrips (Aeolothripidae), carnivorous (predatory and parasitoid) flies (Syrphidae, Empididae, Dolichopodidae, Tachinidae), ichneumonid and braconid wasps (Ichneumonidae, Braconidae), Anagrus wasps (Mymaridae), other parasitoid Hymenoptera (Pteromalidae, Eulophidae, Trichogrammatidae, Scelionidae), spiders (Linyphiidae, Oxyopidae, Clubionidae, Thomisidae, Salticidae), and bees (Apoidea). Bumblebees and larger wasps such as yellowjackets and hornets were usually able to extricate themselves from the sticky material and were rarely trapped and thus not recorded.

\subsection{Data Analysis}

Each site was considered a unit of replication and differences in numbers of arthropods trapped between seasons and years were tested using repeated-measures analysis of variance (ANOVA) with means separated using the Holm-Sidak method for comparing multiple groups (SigmaStat Version 3.0. SPSS Inc., Chicago, IL, USA). Trapping data were $\log (\log x)$ transformed prior to analyses to improve normality of variances and then back-transformed for reporting. 
Table 1. Categories of beneficial arthropods identified and recorded in this study, along with species, genera, and families within each category.

\begin{tabular}{|c|c|}
\hline Beneficial Insect Categories & Species, Genera, or Family Included \\
\hline Neuroptera (Lacewings) & $\begin{array}{l}\text { Chrysoperla plorabunda (Fitch) } \\
\text { Chrysopa nigricornis Burmeister } \\
\text { Chrysopa coloradensis Banks } \\
\text { Chrysopa oculata Say }\end{array}$ \\
\hline Coccinellidae (Ladybeetles) & $\begin{array}{l}\text { Harmonia axyridis (Pallas) } \\
\text { Coccinella septempunctata L. } \\
\text { Coccinella transversogutatta Mulsant } \\
\text { Hippodamia convergens (Guerin-Meneville) } \\
\text { Stethorus picipes Casey } \\
\text { Stethorus punctillum (Weise) }\end{array}$ \\
\hline Heteroptera (Predatory true bugs) & $\begin{array}{l}\text { Deraeocoris brevis (Uhler) } \\
\text { Geocoris pallens Stal } \\
\text { Orius spp. }\end{array}$ \\
\hline Aeolothripidae (Predatory thrips) & $\begin{array}{l}\text { Franklinothrips spp. } \\
\text { Aeolothrips spp. }\end{array}$ \\
\hline Diptera (Predatory and parasitic flies) & $\begin{array}{l}\text { Empididae } \\
\text { Syrphidae } \\
\text { Dolichopodidae } \\
\text { Tachinidae }\end{array}$ \\
\hline $\begin{array}{l}\text { Hymenoptera: Ichneumonidae and Braconidae } \\
\text { (Ichneumonid and braconid wasps) }\end{array}$ & $\begin{array}{l}\text { Ichneumonidae } \\
\text { Braconidae }\end{array}$ \\
\hline Mymaridae (Fairy wasps) & Anagrus spp. \\
\hline Other Hymenoptera & $\begin{array}{l}\text { Pteromalidae, Eulophidae, } \\
\text { Trichogrammatidae, Scelionidae }\end{array}$ \\
\hline Araneae (Spiders) & $\begin{array}{l}\text { Linyphiidae, Oxyopidae, Clubionidae, } \\
\text { Thomisidae, Salticidae }\end{array}$ \\
\hline Apoidea (Bees) & $\begin{array}{l}\text { Apis mellifera L., Andrenidae, Halictidae, } \\
\text { Megachilidae, Apidae, Colletidae }\end{array}$ \\
\hline
\end{tabular}

\section{Results}

No differences in arthropods attracted in each season (spring, summer, autumn) were detected between years or sites and data obtained for each season during the study were combined for analysis. Beneficial arthropods dominated trap catches throughout the study. No herbivorous insects were captured in large numbers. Small numbers $(<1$ individual/trap, all years combined) of thrips (Frankliniella spp.), leafhoppers (Empoasca spp.), and Lygus bugs (Lygus spp.) were recorded but not presented. Grape leafhoppers (Erythroneura spp.) were the most common herbivores, especially in the autumn (mean \pm SE: $28.7 \pm 18.4$ individuals/trap) and spring (11.0 \pm 5.0 individuals/trap) (all years combined).

Combining all categories and analyzed over the entire seasonal study, the mean number of beneficial arthropod individuals attracted was $259.7 \pm 68.8$ individuals/trap. The majority (92\%) of these were hymenopteran parasitoids (238.1 \pm 65.8 individuals/trap). Significantly greater numbers of beneficial arthropods were associated with A. tridentata during autumn (410 \pm 38.2 individuals/trap) than either spring $(181.3 \pm 35.6$ individuals / trap) or summer $(85.1 \pm 24.4$ individuals $/$ trap $)(F=28.06$, df 2, 66; $p<0.001$; Figure 2). Numbers during spring were significantly greater than in the summer. Numbers of hymenopteran parasitoids were also higher during autumn than in spring or summer. Ichneumonid and braconid wasps were significantly more abundant in autumn than spring or summer and more abundant in spring than summer $(F=15.43$, df 2,67; $p<0.001$; Figure 3$)$. The mymarid wasps, Anagrus spp., and the remaining hymenopteran families followed the same trend (Anagrus spp. $F=31.25$, df 2, 67; $p<0.001$; Other Hymenoptera: $F=31.25$, df 2, 67; $p<0.001$; Figure 3). Other beneficial insect groups that were more abundant in the autumn than spring or summer included predatory true bugs (9.2/trap vs. 0.48-0.82/trap) $(F=23.19$, df 2,$67 ; p<0.001$; Figure 3$)$ and carnivorous 
flies (7.8 individuals/trap vs. 3.6-4.8 individuals/trap), although the latter were not significantly so $(F=1.55$, df 2, 67; $p=0.22 ;$ Figure 3$)$.

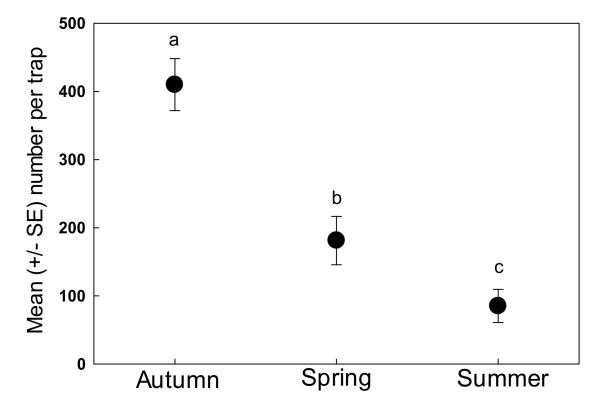

Figure 2. Seasonal abundance of all arthropods associated with A. tridentata in the Yakima Valley, Washington. Different letters denote significant differences $(p<0.001)$.

Three groups of arthropods were significantly more abundant on A. tridentata during spring than either summer or autumn. Ladybeetles and lacewings were common in spring (5.0-5.6 individuals/trap) but rarely seen during summer and autumn (0.22-0.57 individuals/trap) (ladybeetles: $F=22.97$, df 2, 67; $p<0.001$; lacewings: $F=31.25$, df 2, 67; $p<0.001$; Figure 4). Spiders were common in spring (9.6 individuals/trap) with numbers declining in summer (6.5 individuals/trap) to low numbers in fall (2.7 individuals/trap) $(F=13.35$, df 2, 62; $p<0.001$; Figure 4). Bees (4.8 individuals/trap) and predatory thrips ( 0.72 individuals/trap) were commonest in spring but not significantly greater than numbers trapped in spring and autumn (bees: $F=1.85, \mathrm{df} 2$, $67 ; p=0.17$; predatory thrips: $F=2.27, \mathrm{df} 2,67 ; p=0.11$; Figure 4 ).
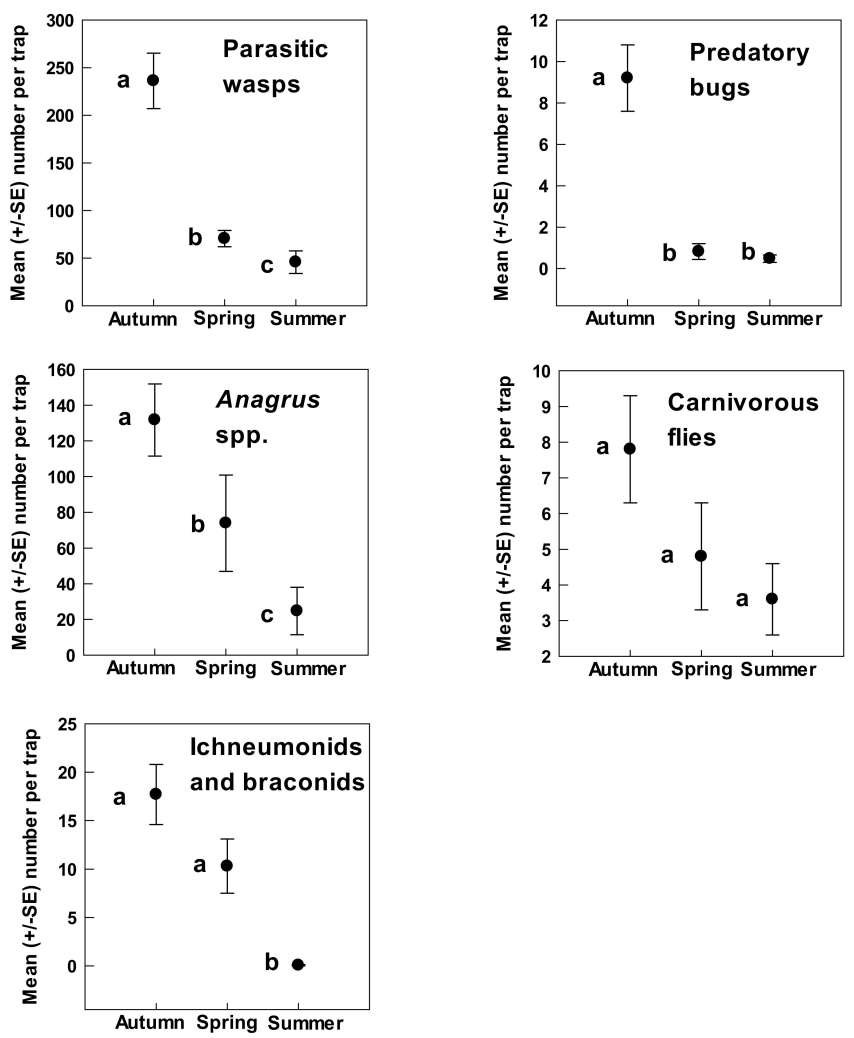

Figure 3. Beneficial insects associated with $A$. tridentata that showed greatest abundance during fall. Different letters denote significant differences $(p<0.001)$. 

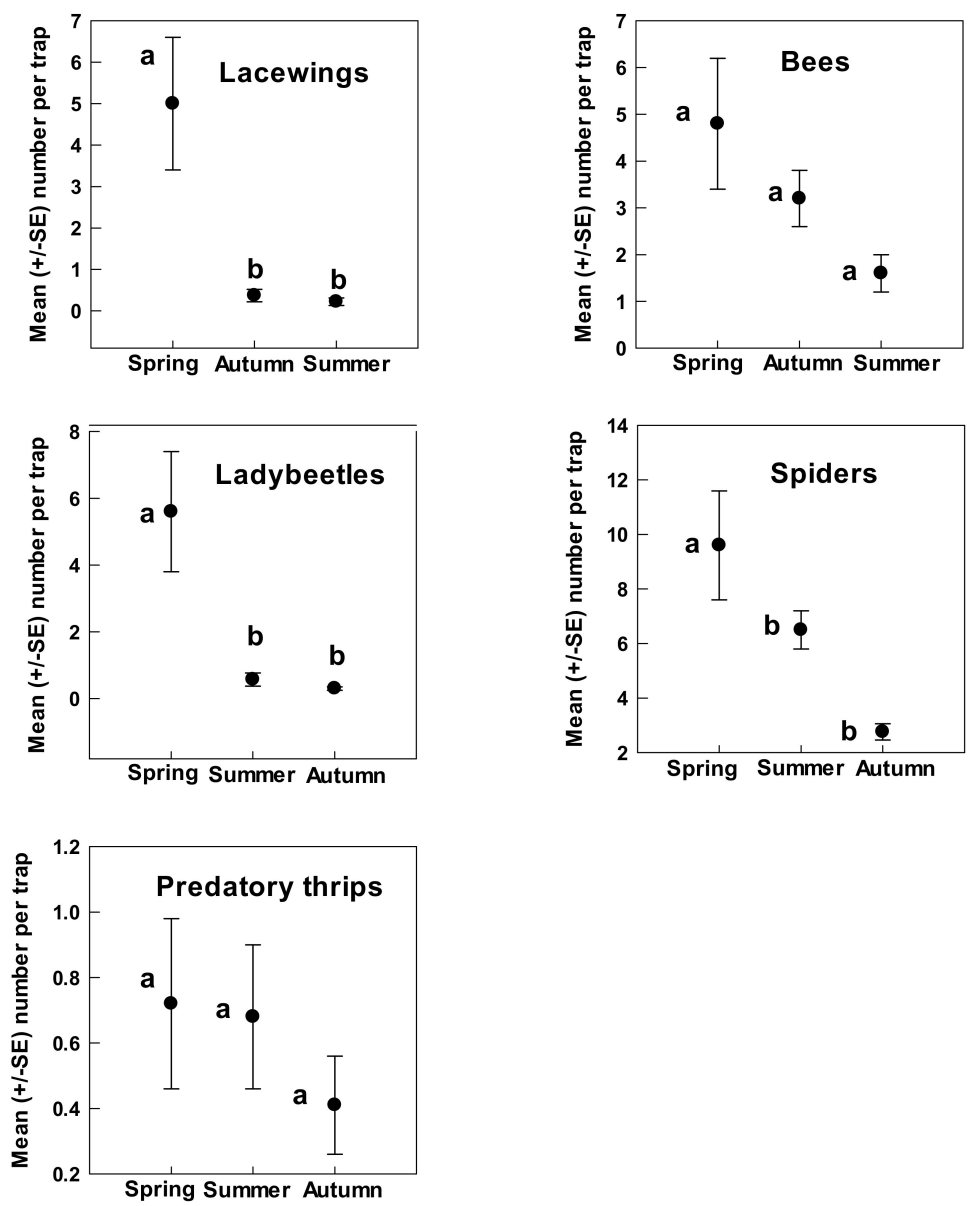

Figure 4. Beneficial arthropods associated with $A$. tridentata that showed greatest abundance during spring. Different letters denote significant differences $(p<0.001)$.

\section{Discussion}

Artemisia tridentata dominates the sagebrush-steppe ecosystem throughout the Pacific Northwest and supports a diverse fauna of arthropods [4,5,12]. Our study provides evidence for the role of A. tridentata in central Washington as a reservoir of a large number of beneficial arthropods, primarily hymenopteran parasitoids throughout the growing season but particularly during autumn and spring. More than $90 \%$ of the beneficial arthropod individuals we recorded on A. tridentata were parasitoid wasps. A large proportion (36\%) of these were individuals of Anagrus spp. (Mymaridae), important biological control agents of grape leafhoppers in wine and juice grape vineyards in central Washington [23]. Anagrus spp. responsible for biological control of grape leafhoppers in eastern Washington (A. daanei, A. erythroneurae, A. tretiakovae) [23] were among the species recorded from A. tridentata in the Yakima Valley. Predatory true bugs, primarily anthocorids (Orius spp.) and geocorids (Geocoris spp.), were the most numerous predatory insects associated with A. tridentata. Increased abundance of parasitoid Hymenoptera, predatory true bugs, and carnivorous flies during the autumn, when A. tridentata blooms, resulted in the greatest seasonal density of beneficial arthropods. However, five groups of beneficial arthropods (lacewings, ladybeetles, predatory thrips, spiders, and bees) showed greatest abundance during spring when no blooms were present. Curiously, we did not trap large numbers of herbivorous insects. Large populations of herbivorous insects like aphids and grasshoppers had a major impact on growth, flower production, and seed set on A. tridentata in Utah [5]. Few grasshoppers were seen at our sampling sites and aphid infestations were not noted. The only abundant herbivores were grape leafhoppers, primarily in autumn and spring, and these probably used A. tridentata for overwintering rather than as a food source [23]. 
Artemisia tridentata is the dominant plant of the sagebrush-steppe ecosystem and might be expected to play an important role in the ecology of many arthropod species living within this system. Our study suggests that its significance extends beyond the provision of nectar during blooming because high numbers of beneficial arthropods were also present during non-blooming periods, particularly in the spring. Beneficial arthropods are associated with $A$. tridentata pre- and post-flowering in eastern Washington, but numbers are about $25-30 \%$ of those recorded during flowering [12]. During a broader study of beneficial arthropods trapped on 100 Yakima Valley native plant species during 2010-2014 (James, unpublished), no other species matched or exceeded the mean number of individuals trapped on $A$. tridentata (259.7 individuals/trap). For example, the mean number of all beneficial arthropods trapped on buckwheats (Eriogonum spp.) ranges from 48.5 to 167.7 individuals/trap [20], on milkweeds (Asclepias spp.) 126-128 individuals/trap [22], and on stinging nettle (Urtica dioica L.) 140 individuals/trap [21]. In many instances, the numbers of beneficial arthropods attracted to non-flowering $A$. tridentata exceeded numbers trapped on flowering native plant species. The association of beneficial arthropods with non-flowering plants has been little studied, but our results and those of $[21,24,25]$ indicate that some plants are attractive to predators and parasitoids throughout the growing season. Some predators and parasitoids may respond to plant cues other than chemicals associated with flowers and may be seeking plant-provided benefits like refuge, mating sites, hosts, and alternative food sources. The relatively large stature and dense structure of $A$. tridentata plants likely makes them an important refuge for arthropods, protecting them from natural enemies and buffering against extremes of heat and cold.

The extremely large numbers of Anagrus spp. associated with A. tridentata in autumn (132 individuals/trap) followed by relatively large numbers in spring (74 individuals/trap) suggests that this species may use the plant for overwintering. However, Anagrus spp. overwinter as eggs within leafhopper eggs. We did not examine twigs and foliage of $A$. tridentata for host leafhoppers, but small numbers of Empoasca spp. leafhoppers were occasionally trapped during the study. A number of leafhopper species have been reported on A. tridentata in Utah [6] and Oregon [9] and it is likely that leafhoppers also feed on sagebrush in Washington. The relationship between Anagrus spp. and A. tridentata deserves further investigation, especially given the importance of these parasitoids to biological control of grape leafhoppers in Washington vineyards [23].

Agricultural development in central Washington invariably involves the removal and fragmentation of shrub-steppe habitat [13]. Sagebrush is the primary plant removed and our study suggests that this also removes a valuable resource of beneficial arthropods that could be utilized in crop pest management. Many of the beneficial arthropods trapped in this study, for example, generalist predators in the families Anthocoridae, Geocoridae, Chrysopidae, and Coccinellidae, are important agents of conservation biological control in regional horticultural crops [26,27]. The degree to which beneficial arthropods move from $A$. tridentata into cropping ecosystems remains unknown and needs further research. However, there are many documented examples of beneficial insect movement from natural ecosystems into adjacent cropland [28,29], and it is likely that at least some movement occurs from $A$. tridentata to nearby crops. In many instances, agricultural land clearing removes far more $A$. tridentata than is actually necessary for crop establishment. Clearing may extend for many meters beyond the crop zone to create a 'neutral space' for reasons of 'tidiness' or creating a perceived pest-free zone. Big sagebrush is not known to harbor significant populations of important crop pests in eastern Washington and our study, with few herbivorous arthropods recorded, supports this notion. We suggest that the clearing of $A$. tridentata during the creation of new agricultural sites be limited as far as possible to retain the important ecosystem services provided by this plant. Fragmented shrub-steppe lands in central Washington adjacent to cropland support a high diversity of beneficial arthropods, although populations were smaller than in undisturbed areas [30]. Thus, it is likely that even limited areas and numbers of $A$. tridentata plants will serve as reservoirs of beneficial arthropods and aid in natural pest management in adjacent cropland. 


\section{Conclusions}

This study provides compelling evidence for the functioning of big sagebrush, A. tridentata, in central Washington as a reservoir of beneficial arthropods throughout spring, summer, and autumn. The majority of beneficial arthropods associated with A. tridentata in this study were hymenopteran parasitoids and greatest numbers occurred during blooming in autumn. Ladybeetles, carnivorous flies, and spiders were commonest during spring. The association of high numbers of predators, parasitoids, and pollinators with $A$. tridentata during blooming and non-blooming periods indicates the potential importance of this wide-ranging landscape plant in the Pacific Northwest to arthropods within the shrub-steppe ecosystem. Ecosystem services like pollination and biological control in agriculture may benefit from proximity to expanses of $A$. tridentata and we recommend utilization of this natural plant resource in planning and maintenance of agricultural lands.

Author Contributions: D.G.J. conceived and designed the experiments; L.S., G.L., and K.B. performed the experiments; D.G.J. analyzed the data and wrote the paper.

Funding: This research was partially funded by the Northwest Center for Small Fruits Research (Grant No. 59-5358-1-429_FR_9-30-14), Western Sustainable Agriculture Research and Education (Grant No. SW 10-052) and the Washington State Wine Grape Industry (Grant No. 10A-3343-0524).

Acknowledgments: We thank the Northwest Center for Small Fruits Research (NCSFR), Western Sustainable Agriculture, Research and Education (WSARE), and the Washington State wine grape industry (WAWGG) for providing partial funding for this research.

Conflicts of Interest: The authors declare no conflict of interest.

\section{References}

1. West, N.E. Western intermountain sagebrush steppe. In Ecosystems of the World: Temperate Deserts and Semi-Deserts; West, N.E., Ed.; Elsevier: Amsterdam, The Netherlands, 1983; pp. 351-374.

2. West, N.E. Intermountain deserts, shrub steppes and woodlands. In North American Terrestrial Vegetation; Barbour, M.G., Billings, W.D., Eds.; Cambridge University Press: Cambridge, UK, 1989; pp. 209-230.

3. Davies, K.W.; Boyd, C.S.; Beck, J.L.; Bates, J.D.; Svejcar, T.J.; Gregg, M.A. Saving the sagebrush sea: An ecosystem conservation plan for big sagebrush plant communities. Biol. Conserv. 2011, 144, 2573-2584. [CrossRef]

4. Sanford, M.P.; Huntly, N.J. Seasonal patterns of arthropod diversity and abundance on big sagebrush, Artemisia tridentata. West. N. Am. Nat. 2010, 70, 67-76. [CrossRef]

5. Takahashi, M.; Huntly, N. Herbivorous insects reduce growth and reproduction of big sagebrush (Artemisia tridentata). Arthropod-Plant Interact. 2010, 4, 257-266. [CrossRef]

6. Takahashi, M. Dynamics of the Interactions between Big Sagebrush (Artemisia tridentata) and Its Associated Arthropods in Southeastern Idaho: Food Webs and Effects of Herbivory in a Changing Climate. Ph.D. Thesis, ProQuest Dissertations Publishing, Idaho State University, Pocatello, ID, USA, 2012.

7. Christiansen, T.A.; Lockwood, J.A.; Powell, A. Arthropod community dynamics in undisturbed and intensively managed mountain brush habitats. Great Basin Nat. 1989, 49, 134-139.

8. Spawton, K.A.; Wetzel, W.C. Gall insect community on big sagebrush varies with plant size but not plant age. Environ. Entomol. 2015, 44, 1095-1100. [CrossRef] [PubMed]

9. Wiens, J.A.; Cates, R.G.; Rotenberry, J.T.; Cobb, N.; Van Horne, B.; Redak, R.A. Arthropod dynamics on sagebrush (Artemisia tridentata): Effects of plant chemistry and avian predation. Ecol. Monogr. 1991, 6, $299-321$. [CrossRef]

10. Abraham, B.J. Spatial and temporal patterns in a sagebrush steppe spider community (Arachnida, Araneae). J. Arachnol. 1983, 11, 31-50.

11. Bolshakova, V.L.J.; Evans, E.W. Phenology of the sagebrush defoliating moth Aroga websteri (Lepidoptera: Gelechiidae), with application to population irruptions. Ann. Entomol. Soc. Am. 2016, 109, 424-431. [CrossRef]

12. Miliczky, E.; Horton, D.R. Natural enemy fauna (Insecta, Araneae) found on native sagebrush steppe plants in eastern Washington with reference to species also found in adjacent apple and pear orchards. Pan-Pac. Entomol. 2007, 83, 50-65. [CrossRef] 
13. Dobler, F.C.; Eby, J.; Perry, C.; Richardson, S.; Vander Haegen, M. Status of Washington's Shrub Steppe Ecosystem; Extent, Ownership and Wildlife/Vegetation Relationships; Phase One Completion Report; Washington Department of Fish and Wildlife: Olympia, WA, USA, 1996; p. 39.

14. Gurr, G.M.; Wratten, S.D.; Barbosa, P. Success in conservation biological control of arthropods. In Biological Control: Measures of Success; Gurr, G.M., Wratten, S.D., Eds.; Springer: Dordrecht, The Netherlands, 2000; pp. 105-132.

15. Fiedler, A.K.; Landis, D.A.; Wratten, S.D. Maximizing ecosystem services from conservation biological control: The role of habitat management. Biol. Conserv. 2008, 45, 254-271. [CrossRef]

16. Gurr, G.M.; Scarratt, S.L.; Wratten, S.D.; Berndt, L.; Irvin, N. Ecological engineering, habitat manipulation and pest management. In Ecological Engineering for Pest Management: Advances in Habitat Manipulation for Arthropods; Gurr, G.M., Wratten, S.D., Altieri, M.A., Eds.; CSIRO Publishing: Melbourne, Australia, 2004; pp. 1-12.

17. Cunningham, R.B.; Lindenmayer, D.B.; Crane, M.; Michael, D.; Macgregor, C. Reptile and arboreal marsupial response to replanted vegetation in agricultural landscapes. Ecol. Appl. 2007, 17, 609-619. [CrossRef] [PubMed]

18. Fahrig, L.; Baudry, J.; Brotons, L.; Burel, F.G.; Crist, T.O.; Fuller, R.J.; Sirami, C.; Siriwardena, G.M.; Martin, J.L. Functional landscape heterogeneity and animal biodiversity in agricultural landscapes. Ecol. Lett. 2011, 14, 101-112. [CrossRef] [PubMed]

19. James, D.G.; Lauby, G.; Seymour, L.; Buckley, K. Beauty with Benefits: Butterfly conservation in Washington State, USA, wine grape vineyards. J. Insect Conserv. 2015, 19, 341-348. [CrossRef]

20. James, D.G.; Seymour, L.; Lauby, G.; Buckley, K. Beneficial insects attracted to native flowering buckwheats (Eriogonum Michx) in central Washington. Environ. Entomol. 2014, 43, 942-948. [CrossRef] [PubMed]

21. James, D.G.; Lauby, G.; Seymour, L.; Buckley, K. Beneficial insects associated with stinging nettle (Urtica dioica Linnaeus) in central Washington State. Pan-Pac. Entomol. 2015, 91, 1-9. [CrossRef]

22. James, D.G.; Seymour, L.; Lauby, G.; Buckley, K. Beneficial insect attraction to milkweeds (Asclepias speciosa, Asclepias fascicularis) in Washington State, USA. Insects 2016, 7, 30. [CrossRef] [PubMed]

23. Prischmann, D.A.; James, D.G.; Storm, C.P.; Wright, L.C.; Snyder, W.E. Identity, abundance and phenology of Anagrus spp. (Hymenoptera: Mymaridae) and leafhoppers (Homoptera: Cicadellidae) associated with grape, blackberry and wild rose in Washington State. Ann. Entomol. Soc. Am. 2007, 100, 41-52. [CrossRef]

24. Frank, S.D.; Shrewsbury, P.M.; Esiekpe, O. Spatial and temporal variation in natural enemy assemblages on Maryland native plant species. Environ. Entomol. 2008, 37, 476-486. [CrossRef]

25. Xavier, S.S.; Olson, D.M.; Coffin, A.W.; Strickland, T.C.; Schmidt, J.M. Perennial grass and native wildflowers: A synergistic approach to habitat management. Insects 2017, 8, 104-116. [CrossRef] [PubMed]

26. Prischmann, D.A.; James, D.G.; Gringras, S.N.; Snyder, W.E. Diversity and abundance of insects and spiders on managed and unmanaged grapevines in southcentral Washington State. Pan-Pac. Entomol. 2005, 81, 131-144.

27. Woods, J.L.; Dreves, A.J.; James, D.G.; Lee, J.C.; Walsh, D.B.; Gent, D.H. Development of biological control of Tetranychus urticae Koch (Acari: Tetranychidae) and Phorodon humuli (Schrank) in Oregon hop yards. J. Econ. Entomol. 2014, 107, 570-581. [CrossRef] [PubMed]

28. Barral, M.P.; Rey Benayas, J.M.; Meli, P.; Maceira, N.O. Quantifying the impacts of ecological restoration on biodiversity and ecosystem services in agroecosystems: A global meta-analysis. Agric. Ecosyst. Environ. 2015, 202, 223-231. [CrossRef]

29. Liu, B.; Yang, L.; Zeng, Y.; Yang, F.; Yang, Y.; Lu, Y. Secondary crops and non-crop habitats within landscapes enhance the abundance and diversity of generalist predators. Agric. Ecosyst. Environ. 2018, 258, 30-39. [CrossRef]

30. Quinn, M.A. Influence of habitat fragmentation and crop system on Columbia Basin shrubsteppe communities. Ecol. Appl. 2004, 14, 1634-1655. [CrossRef]

(C) 2018 by the authors. Licensee MDPI, Basel, Switzerland. This article is an open access article distributed under the terms and conditions of the Creative Commons Attribution (CC BY) license (http:/ / creativecommons.org/licenses/by/4.0/). 